\title{
Saddam Hussein 1937-2006
}

Helle Lykke Nielsen

\section{En af verdens mest brutale og hensynsløse diktatorer er blevet henrettet ved en irakisk domstol}

Iraks ubestridte leder gennem 24 år, Saddam Hussein, blev 69 år. Eller måske blev han kun 67 , for ingen ved rigtigt, om han var født i 1937 eller 1939. Og netop usikkerheden om selv så grundlæggende ting som en fødselsdato, var karakteristisk for Saddam: Blev han gift en, to - eller sågar tre - gange? Hvor boede han? Havde han virkelig dobbeltgængere, og i givet fald hvor mange? Hvor befandt han sig egentlig de sidste år af sin regeringsperiode, hvor irakerne nærmest kun så ham på tv? Hvordan gemte han sig for amerikanerne efter Bagdads fald i april og frem til han blev fanget i december 2003, og hvad fik han tiden til at gå med i sin celle i de næsten tre år han måtte tilbringe i amerikansk fangenskab? De mange ubesvarede spørgsmål og verserende rygter gjorde Saddam til en myte, som både arabiske og vestlige medier på hver deres måde bidrog til at holde i live.

Saddams vej mod magten var præget af brutalitet. Ud over mordet på en lokal kommunistleder i 1958 deltog han i tre kupforsøg mod henholdsvis præsident Qassem i 1959, præsident Arif i 1964 og dennes bror i 1968 - det forsøg der endeligt førte Bath-partiet til magten i Irak. Fra 1968 og frem til 1979, hvor han selv blev præsident, var efterretningstjenesterne hans vigtigste platform. Hans erfaringer med at opbygge Bath-partiets efterretningstjeneste fra $1964 \mathrm{og}$ frem blev flittigt brugt i perioden, hvor han i bedste stalinistiske stil overvågede alt og alle gennem et vidt forgrenet net af informanter, embedsmænd og politiske kommissærer. Samtidig fik han marginaliseret præsident al-Bakr ved langsomt at overtage centrale opgaver og sideløbende indsætte familie og venner på vigtige poster. Det lykkedes i en sådan grad, at den egentlige magtovertagelse i 1979 kun var en proformasag: Saddam mødte op hos al-Bakr den 16. juli sammen 


\section{HELLE LYKKE NIELSEN}

med sin fætter der var forsvarsminister, og sin onkel der senere blev borgmester i Bagdad, og præsenterede ham for et fait accompli. Dagen efter, på den irakiske nationaldag, trak præsidenten sig og udnævnte Saddam til sin efterfølger. Al-Bakr døde tre år senere af en overdosis insulin, angiveligt bestilt af Saddam.

Saddam Hussein var et farligt bekendtskab - ikke blot for den irakiske befolkning, der måtte leve med tortur, etniske udrensninger og endda giftgasangreb. Selv Saddams meget betroede folk havde det med at afgå ved døden på de mest belejligede tidspunkter: Mange har undret sig over, at der var langt flere militærfolk der døde ved helikopterulykker i fredstid end i krigstid. Saddam var endda villig til egenhændigt at myrde sine ministre, som det skulle være sket ved et ministermøde i 1982, hvor sundhedsminister Riyadh Ibrahim Hussein var så uforsigtig at foreslå noget, der ikke passede præsidenten.

\section{Fra Nahda til Nakba}

Saddam var ubetvivleligt en populær præsident, da han overtog posten efter al-Bakr i 1979. Det var de gode år i slutningen af 1970'erne og begyndelsen af 1980'erne, hvor olieindtægterne begyndte at strømme ind og løbende blev omsat i skoler, universiteter, hospitaler, gode veje, store fabrikker, udvikling af landbrugssektoren - kort sagt, en udvik- ling af det irakiske samfund, som kan sammenfattes med det arabiske ord $a l-N a h d a$, der på en gang betyder 'renæssance', 'opblomstring' 'fremskridt', ja selv 'national vækkelse'. Den irakiske Nahda blev beundret af mange, ikke kun i Irak, men også i resten af den arabiske verden.

Vejen fra al-Nahda mod al-Nakbakatastrofen - blev langsomt, men sikkert indledt, da Saddam i 1980 besluttede sig for at angribe Iran. Han var, lige som resten af verdens statsledere, utryg ved det nye præstestyre i Teheran, der var kommet til magten efter Shahens fald i 1979, og frygtede, at shiitiske grupper i det sydlige Irak ville lade sig inspirere af Khomeini til at forsøge også at vælte styret i Bagdad.

Med støtte fra såvel arabiske lande som Vesten begav Saddam sig derfor ud i en krig mod den store nabo, som han ikke kunne vinde. Krigen bølgede frem og tilbage over fronten i otte år med meget store menneskelige og økonomiske tab på begge sider, og selv om Saddam flere gange forsøgte at få en våbenhvile i stand, lykkedes det først i 1988. Da var den irakiske befolkning udmattet, statskassen tom, Irak var verdens tredje mest forgældede land, og Saddams popularitet kunne følgelig ligge på et meget lille sted.

Derefter gik det slag i slag ned ad bakke. Invasionen af Kuwait, der i Saddams øjne skulle have løst landets økonomiske problemer, blev i stedet en katastrofe, både militært 
og økonomisk. De efterfølgende sanktioner, der kom til at vare i 12 år, satte hans styre under pres, men dog ikke mere, end at han med vanlig overlevelsesevne formåede at finde veje ud af de økonomiske problemer, og fx trods sanktionerne formåede at bygge seks nye paladser med krystallysekroner, guldbelagte vandhaner og anden luksus. Imens led den irakiske befolkning af mangel på mad, medicin og helt dagligdags fornødenheder.

\section{Saddams mission}

Saddam mente selv, at han havde en mission: Det var hans opgave at holde den irakiske nationalstat sammen på tværs af etniske og religiøse skel, og vel at mærke med ham som leder. Og det lykkedes rent faktisk, om end midlerne var meget brutale. Nøgtern set var det ikke nogen ringe bedrift, når man tager antallet af kup, kupforsøg og fraværet af stabilitet i betragtning i perioden fra kongedømmets fald i 1958 og frem til Saddams magtovertagelse i 1979. At det stadig er en vanskelig opgave, også efter Saddams styre er væltet, vidner begivenhederne i Irak os dagligt om.

Men Saddam ville mere end det: Han ville gengive Irak dets historiske rolle, som det havde haft i det gamle Mesopotamien, og dermed placere sig selv og Irak som centrum i den arabiske verden. Han ville være den leder, der forenede den arabiske verden, så den udgjorde et værdigt alternativ til Vesten. Den del af opgaven lykkedes ikke.

Ganske som de middelalderlige fyrster formåede Saddam Hussein at holde sit land og sin befolkning i et jerngreb. Midlerne dertil var skrappe: en totalitær stat med effektive efterretningstjenester, et velstruktureret Bath-parti, særlige korps af bodyguards og specialtrænede elitesoldater var de synlige tegn på Saddams enevældige magt.

Til gengæld fejlvurderede han ofte verden uden for landets grænser. Han kunne ikke vinde over Iran, kunne ikke besejre Kuwait, kunne ikke få ophævet sanktioner trods de mange kunstgreb, han forsøgte sig med. Det var egentlig ikke overraskende al den stund, at han aldrig rigtig havde set verden omkring sig på andet end en tv-skærm.

Bortset fra nogle års eksil i Cairo efter det mislykkede kupforsøg mod præsident Qassem i 1959 var han i Paris og USSR en enkelt gang og rejste i få tilfælde rundt i det arabiske område for at samle støtte til sine krigsplaner. Journalister der har interviewet ham, beretter samstemmende om, hvordan de efter interviewet blev trukket ind i et tilstødende lokale og på tomandshånd udspurgt om, hvem der bestemte i USA, hvordan man blev præsident $\mathrm{i}$ Frankrig etc. etc. Et sådant begrænset verdenssyn måtte give problemer i en verden, der blev stadig mere international og globaliseret. 
Og i 2003 var det så slut. Også her kom udfordringen udefra - fra et USA, der som verdens eneste supermagt havde besluttet sig for at gøre en ende på Saddam Husseins legen kispus med FN's våbeninspektører og det internationale samfund.

At de amerikanske krav om våbeninspektion og udlevering af terrormistænkte må have forekommet Saddam uforenelige med de hensyn han nødvendigvis måtte tage til de grupper, organisationer og militære midler, han byggede sin indenrigspolitiske magt på, kan man få en fornemmelse af ved at se på de løsninger, han valgte. I stedet for at gå betingelsesløst ind på de amerikanske krav valgte han med vanlig taktisk snilde at forsøge at løse konflikten ved at spille det internationale samfund ud mod hinanden i håb om, at det kunne tage en eventuel krig i opløbet.

Det lykkedes da også at få skabt et modsætningsforhold mellem USA og Storbritannien på den ene side og Rusland, Frankrig og Tyskland på den anden, men det havde ikke den $\varnothing n s k e d e$ effekt. For USA valgte sammen med Storbritannien at gå i krig uden et FN-mandat bakket op af et mindre antal lande, heriblandt Danmark, og det blev Saddams politiske endeligt. Efter tre ugers krigsførelse indtog de amerikanske og britiske soldater Bagdad den 9. april 2003, og den væltede kæmpestatue af Saddam på Firdaws-pladsen blev det symbolske bevis på, at 24 års totalitært styre under Saddam nu var slut.

\section{Saddams endeligt}

Da Saddam mistede magten i 2003, var det irakiske samfund allerede i opløsning. Tre krige og 12 års økonomiske sanktioner havde nedslidt og udsultet det irakiske samfund i en sådan grad, at man med rimelighed kan tale om et Nakba - det arabiske ord for katastrofe.

At Saddam var en færdig mand, også i irakiske øjne, blev for alvor tydeligt, da amerikanske styrker den 13. december 2003 hev den tidligere diktator op af en jordhule - "fanget som en rotte i et hul", som en amerikansk general udtrykte det. Billedet af en kujon, der gemte sig under jorden med en stor bunke penge, to maskinpistoler og en revolver, og end ikke turde løsne et skud, da han blev opdaget - hverken mod sig selv eller dem, der fandt ham - men blot overgav sig uden modstand, var selvsagt ynkeligt.

Men Saddam formåede at rejse sig igen. Efter to års fangenskab på en amerikansk base i Bagdad blev den første retssag mod ham indledt den 19. oktober 2005, og det blev netop den platform, den tidligere diktator havde brug for, til at skabe sig oprejsning i irakiske øjne. Under sagen, der omfattede anklager for mord på 148 shiamuslimske mænd, kvinder og børn i landsbyen Dujail i 1982, benyttede Saddam enhver given lejlighed til at omtale sig selv som 'Iraks legitime præsident der er valgt af alle irakere', og med kora- 
nen i hånden understrege sin hengivenhed for islam. Amerikanerne derimod var besættere der ud over at torturere ham førte korstog mod muslimerne, splittede den irakiske nation, og alene var ude på at stjæle Iraks sorte guld.

Saddam var som altid meget opmærksom på sin fremtoning og fremsatte flere gange under sagen klager over, at han stadig måtte gå i de sko han bar, da han blev arresteret i december 2003, og at han ikke kunne få dagligt bad og rene skjorter under retssagen. Til gengæld fik han lov at farve sit hår inden første retsmøde, hvis man ellers skal tro hans advokat.

Under retsmøderne, der blev transmitteret forskudt på irakisk tv, erklærede Saddam flere gange at han ikke var bange for at $d \varnothing$ : "Ingen af os er bange for at $d \varnothing$. Det vigtigste for mig er at tilfredsstille Allah og menneskeheden, og at det amerikanske folk får at vide, hvad deres herskere har gjort mod den irakiske nation”. Han gik endda så langt som til at bede om - ja nærmest kræve at blive henrettet ved skydning, sådan som det ifølge Saddam passede sig for en mand af militær rang.

Sagen endte med en dødsdom den 5. november 2006. Og den 30. december, fire dage efter at en appelret havde stadfæestet dommen, blev Saddam henrettet ved hængning i et lokale, der tidligere havde været brugt af de irakiske efterretningstjenester, han selv havde stået i spidsen for. Og billederne af henrettelsen gik verden rundt: Først i en officiel video-version som det irakiske styre frigav kort efter henrettelsen. Den viste en fattet Saddam som uden bind for øjnene roligt lod bødlerne lægge løkken om sin hals og gik værdigt i døden med Koranen i hånden, mens han fremsagde den islamiske trosbekendelse.

Og dagen efter i en uofficiel version, optaget ulovligt af en af de tilstedeværende, sandsynligvis med et kamera fra en mobiltelefon. Den optagelse, der også omfattede lyd, viste langt mere tumultagtige tilstande: En skarp ordveksling mellem Saddam og nogle af de tilstedeværende, fornærmelser og tilråb uden for lokalet til støtte for den shiamuslimske imam Muqtada alSadr, der var en af Saddams argeste modstandere, gav et tydeligt billede af den spændte atmosfære af politiske og religiøse konflikter, som henrettelsen fandt sted $i$.

Også datoen for henrettelsen var omstridt: den 30. december 2006 var officielt første dag i den islamiske højtid Eid al-Adha, den såkaldte offerfest hvor muslimer fejrer at profeten Ibrahim (Abraham) var villig til at ofre sin søn Ismail til Gud. At Saddams henrettelse netop fandt sted på denne helligdag, der ifølge mange muslimer burde stå for tolerance og fællesskab, blev opfattet som både fornærmende og en måde at vanhellige islam og genere Saddam på. 


\section{HELLE LYKKE NIELSEN}

Men ikke nok med det: At vælge den 30. december afspejlede også en intern religiøs splittelse. For ifølge nogle shiamuslimske lærde begynder Eid al-Adha først en dag senere i den shiamuslimske tradition end i den sunnitiske, så ved at henrette Saddam den 30. december, provokerede Iraks shiamuslimske ledere kun sunnimuslimer, ikke shiamuslimer. Det der skulle have forenet (størstedelen af) den irakiske befolkning i opgøret med den tidligere diktator, blev således på flere måder i stedet et symbol på den stigende splittelse mellem irakiske sunni- og shiamuslimer.

Trods billederne fra henrettelsen og udleveringen af Saddams lig til stammeledere i Tikritområdet hvor Saddam blev begravet dagen efter henrettelsen, er der alligevel folk, der offentligt mener at vide, at Saddam slet ikke er blevet henrettet - at det i virkeligheden var en af hans påståede dobbeltgængere ved navn Makhluf Ramadhan, der blev hængt og lagt i jorden. Beviserne herfor skulle være af fysisk art: En skønhedsplet på panden, størrelsen og formen af ørerne, og den måde den fængslede talte dialekt på under retssagen, var alt sammen tegn på at det var en anden end den rigtige Saddam, der var blevet ført til skafottet.

En universitetsunderviser i matematik og statistik fra Cairo Universitet, Adil Ali al-Qadir, hævder endog på basis af en matematisk teori at have regnet sig frem til, at Saddam i virkeligheden var blevet befriet fra sit fængsel af arabiske mujahidinere, længe før henrettelsen fandt sted.

\section{Kampen om Saddams eftermæle}

Saddams henrettelse indskrev sig i det forværrede forhold mellem irakiske sunni- og shiamuslimer som for alvor eskalerede i 2006. Og bedre blev det ikke, da Saddams halvbror, Barzan Ibrahim al-Tikriti, der sammen med en tidligere chefdommer var dømt i samme sag som Saddam, blev henrettet to uger senere. Ved hængningen blev Barzans hoved nemlig skilt fra kroppen og rullede dramatisk ned på gulvet, hvilket for mange irakiske sunnimuslimer var endnu et eksempel på den ydmygelse, de har måttet lide efter Saddam-styrets fald.

Men måske netop på grund af den i forvejen eskalerende vold i Irak synes henrettelserne ikke at have fremkaldt de voldsomme reaktioner, som mange politiske iagttagere af situationen i Irak havde forudsagt. Saddams henrettelse var ventet, og selv om den utvivlsomt har provokeret de i forvejen pressede sunnimuslimer og bidraget til at øge spændingerne, kan man ikke sætte fingeren på attentater eller andre større begivenheder, som skulle være forårsaget af henrettelsen.

Henrettelsen af Saddam er utvivlsomt blevet fulgt med tilbageholdt åndedræt af de arabiske regimer - 
at se en arabisk leder blive retsforfulgt, dømt og henrettet af sine egne må nødvendigvis få det til at løbe koldt ned ad ryggen på mange mellemøstlige ledere.

Alligevel var de første officielle arabiske reaktioner meget afdæmpede. Bortset fra Libyens oberst Qadhafi der straks erklærede tre dages landesorg, og den kuwaitiske parlamentsformand Jassim Al-Kharafi der i lyset af den irakiske besættelse af Kuwait i 1990-91 omvendt anså dødsdommen for retfærdig - og "offerfesten dobbelt så glædelig nu da Saddam Husseins dødsdom er blevet eksekveret" - begrænsede de fleste officielle arabiske reaktioner sig til at udtrykke utilfredshed med valget af datoen, men udtalte sig ikke om selve henrettelsen.

Den ægyptiske præsident Mubarak var nok den arabiske leder der mest direkte kritiserede henrettelsen, da han i et interview med den israelske avis Yedioth Ahronoth den 5. januar 2007 udtalte at man med valget af dato kombineret med de voldsomme billeder fra henrettelsen risikerede at gøre Saddam til martyr.

Og selvom Mubaraks udtalelse kan forekomme skinger for dem der kender til Saddams mange ugerninger, kan den vise sig at holde stik. Det skyldes at den regionale udvikling i Mellemøsten er under pres i disse år, hvor Iran forsøger at udbrede sin magt i området, ikke blot gennem etablering af et atomprogram og støtte til forskellige shia- muslimske militser i Irak, men også ved at sende våben og penge til Hizbollah og Hamas.

Den udvikling har sammen med optrapningen af konflikten mellem Iran og USA sat de arabiske regimer under voldsomt pres, og der er ved at brede sig en opfattelse i regionen, både blandt arabiske ledere og befolkningsgrupper, af at den arabiske verden i dag sidder i en voldsom klemme mellem Irans regionale stormagtsdrømme, Israels hårdtslående gengældelsesangreb og en overordnet amerikansk plan der har til formål at sikre sig total kontrol med det arabiske område og dets ressourcer.

I en sådan kontekst er det ikke svært at forestille sig, at en henrettet arabisk hersker som Saddam kan gå hen og få martyrstatus: Otte års krig mod Iran, to krige mod USA og en konsekvent anti-israelsk diskurs der af og til blev understøttet af symbolangreb på Israel, taler sit eget sprog og omfatter det stof, mange arabiske helte er gjort af.

\section{Politisk ikon}

Den toneangivende sunnimuslimske sheik Yusuf al-Qaradhawi, der både har sit eget tv-program på al-Jazeera og sidder i diverse sunnimuslimske råd og kommissioner, tog allerede nogle dage efter Saddams henrettelse hul på den proces. I en udsendelse på al-jazeera den 5. januar 2007 sagde han bl.a. at der var tale om 


\section{HELLE LYKKE NIELSEN}

"en amerikansk retssag. De (amerikanerne) vil have bugt med manden (Saddam), som de ikke kunne vride halsen om på, og hvis vilje de ikke kunne knække. Det er den mand der sendte 39 missiler ind over Israel, hvad Israel aldrig har glemt, den mand hvis atomreaktor de ødelagde (...). Det er den mand der livet igennem kæmpede for den palæstinensiske sag. Det er den mand der sagde 'nej' til amerikanerne... (...) I sine sidste år - det har vore brødre i Irak fortalt os - var han helt forandret. Han begyndte at bede, læse Koranen og lave velgørende arbejde. Han gjorde alt hvad han kunne for at hjælpe folk. Han hjalp med at bygge moskeer og lovede (...) at betale halvdelen af byggematerialerne. Da de (amerikanerne) trængte ind i hans hemmelige skjul og fangede ham, fandt de et bedetæppe og en åben Koran."

Mens arabiske og islamiske grupper uden for Irak således allerede er begyndt at bruge Saddam som politisk ikon til egne formål, hviler Saddams arv tungt over den irakiske befolkning og vil utvivlsomt gøre det i generationer fremover. 24 års voldeligt diktatur har ikke blot forårsaget død og ødelæggelse, splittet familier og ført Irak på fallittens rand, men har også sat sig dybe spor i den måde, folk tænker og agerer på.
Det shiamuslimske parlamentsmedlem Iyad Jamal al-Din beskrev det i et interview på al-jazeera den 28. december 2006 således: "I det øjeblik Saddams mænd blev løftet væk over vores hoveder, ønskede vi alle sammen at indtage Saddams personlighed. (Tidligere) havde vi en Saddam, nu har vi seks, syv, 10 eller 15 Saddam'er. Vi har lokale mini-Saddam'er..."

Henrettelsen af den tidligere irakiske diktator er således næppe det sidste, vi kommer til at høre om Saddam: For ganske vist kan en mand kun henrettes en gang, men dels ligger der andre og mere omfattende sager og venter på at blive behandlet i det irakiske retsopgør, hvilket utvivlsomt vil oprulle flere af Saddams ugerninger, dels vil kampen om Saddams eftermæle fortsætte en rum tid endnu.

Saddam ønskede at være en stor mand, både i sin samtid og for eftertiden. $\mathrm{Og}$ hvem ved: Måske får han sit ønske opfyldt, for som han sagde: "Det er ikke vigtigt, hvad irakerne siger om mig i dag - det vigtige er derimod, hvad araberne vil sige om 500 år."

Helle Lykke Nielsen er lektor ved Center for Mellemøststudier, Syddansk Universitet. 


\section{Fra Aljazeera: Hizbollah}
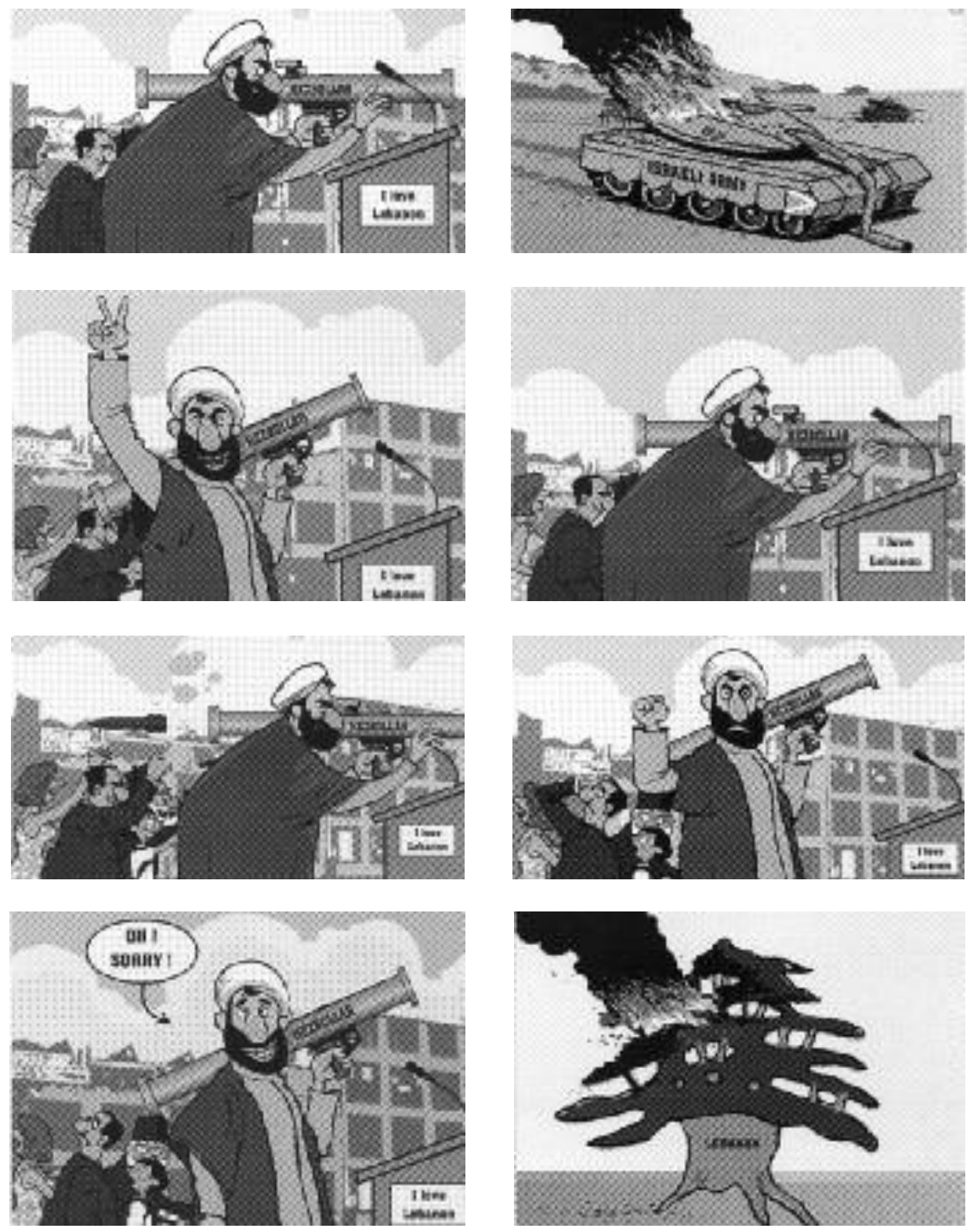

udenrigs $1 \cdot 2007$ 